\title{
Chapter 1 \\ Divination and the human body
}

\section{Body signs in context}

'Physiognomy is the prejudice coagulated in book form'1 says Hans Blumenberg in The Legibility of the World with reference to Lichtenberg's physiognomy criticism, which is inspired by Lavater's interpretative optimism and ironically sketches a frightening scenario:

\begin{abstract}
Wenn die Physiognomik das wird, was Lavater von ihr erwartet, so wird man die Kinder aufhängen, ehe sie die Taten getan haben, die den Galgen verdienen, es wird also eine neue Art von Firmelung jedes Jahr vorgenommen werden. Ein physiognomisches Auto da Fe.

(Lichtenberg 1983, F 517)
\end{abstract}

[If physiognomy becomes what Lavater expects it to be, children will be hung before they have done the deeds that deserve the gallows, so a new type of confirmation will be made every year. A physiognomic Auto-da-Fé.]

In early modern times, the problem horizon against which physiognomics is to be considered was a slightly different one: The doctrine of the reading of body signs, especially when it projected its thirst for knowledge into the future, came into conflict with the concept of human freedom of will, a concept which was controversially discussed ever since the polemical dispute between Luther and Erasmus and which had acquired a dogmatic character for Catholic Spain since the Tridentinum. The determinism inherent in physiognomics and related disciplines thus had to be reconciled with the prevailing theological discourse, which endowed man with a liberum arbitrium. One way of coping with predestination which is inherent in the nature of these disciplines was to interpret the physiological dispositions as inclinatio, an inclination which could be countered by virtuous action. The legitimacy of physiognomic interpretation, which is repeatedly negotiated in the prologues of the relevant tracts, was established in very different ways. Particularly instructive in this context is the Commentarius de praecipuis generibus divinitationem, published in 1553 in Wittenberg by Caspar Peucer. The German reformer answers the question "Quod sint aliqua divinationum genera non impia, nec superstitiosa, et Christianis concessa” $(1553,1 r)$ [Which are the forms of divination neither impious nor superstitious and permitted for Christians] for such different fields of knowledge as physiognomy, chiromancy

1 “Physiognomik ist das in Buchform geronnene Vorurteil”, Blumenberg (1981, 201).

Ә Open Access. ( 2021 Folke Gernert, published by De Gruyter. (c) BY-NC-ND This work is licensed under the Creative Commons Attribution-NonCommercial-NoDerivatives 4.0 International License. 
and astrology by saying that in all cases signs, with God's permission, can be interpreted by men.

Conceptually, physiognomy works like other semiotic practices that interpret different body signs, especially chiromancy and metoposcopy, but also the reading of moles or birthmarks. Unlike chiromancy and perhaps metoposcopy, physiognomy is not, in the first place, one of the artes manticae, ${ }^{2}$ although the reading of body signs since classical antiquity ${ }^{3}$ has also been used to know the future. ${ }^{4}$

La physiognomonie n'entre dans le champ de la divination que dans la mesure où elle prétend prédire la destinée de l'homme d'après les traits de son visage et l'aspect général

2 See about divination Aphek \& Tobin (1989), Bloch (1991), Burnett (1996), Minois (1996), Boudet (2006) and Tuczay (2012) and Annus (2010) for divination practices in the ancient world. On divination and forecasting of the future there is also a whole series of collective volumes with highly specialised contributions; see the publications edited by Hogrebe (2005), Bergdolt and Ludwig (2005), Sturlese (2011), Fidora (2013) and Boudet, Ostorero \& Paravicini Bagliani (2017).

3 According to Dasen ancient physiognomy “could also have a predictive dimension” $(2014,155)$. The researcher refers to the treatise of the Latin anonymous, in which "one reads that 'Polemon and Loxus advance this discipline to such an extent that they affirm it can predict some things in the future"' (Dasen 2014, 155). For other practices that read the future from the human body, see Dasen (2008), Chandezon, Dasen \& Wilgaux (2013) who observe: "Dans le monde grec antique, tout, dans le corps humain, peut devenir signe et faire l'objet d'une interprétation. De l'art médical à la physiognomonie, en passant par la mantique, de nombreuses technai ont développé une sémiologie du corps qui relèvent d'une façon commune de penser le corps et de chercher à le déchiffrer, mais avec des finalités différentes [. . .] Ces technai ont progressivement affirmé leur autonomie tout en s'intéressant aux mêmes signes corporels, et les indices de la porosité de leurs frontières abondent. Comme la mantique, la physiognomonie peut ainsi accorder aux mouvements du corps une valeur de présage, tandis que l'art médical utilise l'observation de signes pour établir un pronostic et anticiper l'évolution de la maladie." (111). [In the ancient Greek world, everything in the human body can become a sign and be interpreted. From medical art to physiognomy, through mantic art, many technai developed a semiology of the body which is based on a common way of thinking about the body and trying to decipher it, but with different purposes . . . These technai have gradually asserted their autonomy while being interested in the same body signs, and clues to the porosity of their boundaries abound. Like divination, physiognomy can thus give body movements an omen value, while medical art uses the observation of signs to establish a prognosis and anticipate the evolution of the disease].

4 See Bordes (2003, 308): "La adivinación es el instrumento de trabajo común en el análisis del fisiognomista, pero algunos autores interpretan los signos externos del cuerpo no para establecer una correspondencia con el carácter, sino para realizar unas suposiciones sobre el pasado o futuro individual." [Divination is the common working tool in the analysis of the physiognomist, but some authors interpret the external signs of the body not to establish a correspondence with the character, but to make some assumptions about the individual past or future]. 
de son corps. Mais plus généralement, elle vise à connaître les mœurs et les passions d'un individu par l'examen de ses caractères physiques. (Boudet 2006, 114)

[Physiognomy enters the field of divination only insofar as it claims to predict man's destiny according to the features of his face and the general appearance of his body. But more generally, it aims to know the morals and passions of an individual by examining his physical characteristics.]

It is precisely the divinatory dimension that influences the legitimacy of these practices and which is the reason why physiognomy is often considered - unlike chiromancy and metoposcopy - as a licit practice. The reading of body signs as a technique to know the future is often associated with the world of magic. In fact, some specialised studies on magic and witchcraft include chapters on physiognomy, chiromancy and other divinatory practices. ${ }^{5}$ However, as Rapisarda rightly observes, "magia e divinazione sono due pratiche in realtà 'epistemologicamente' assai differenti" $(2005,233)$ [magic and divination are two practices that are actually 'epistemologically' very different]. The former "mira a modificare con procedure 'costrittive' la realtà esterna all'individuo" [aims to modify the reality outside of the individual with 'coercive' procedures] while the latter is dedicated to the "prescienza del futuro" $(2005,233)$ [foreknowledge of the future]. As the aforementioned Italian researcher explains, the confusion is already present in Isidore of Seville and is particularly palpable in the case of necromancy, which lost its etymological meaning ('divination through the dead') and came to designate 'black magic'.

It is with natural magic that physiognomy and related semiotic practices share a conceptual basis. The planetary influence that is supposed to be represented in the mountains of the hand or in the lines of the forehead can be considered, as well as the external corporal signs, indicative of the inner and invisible virtues of a person, a sort of qualitas occulta comparable to the force that the stone magnet exerts on the metals or the healing effect of a talisman. ${ }^{6}$ As Foucault says, "dans une epistémè où signes et similitudes s'enroulaient

5 See Boudet (2006), Tuczay (2012) and recently Zamora Calvo (2016), who devotes short chapters of her study of the Artes maleficorum to metoposcopy (99), physiognomy (101) and chiromancy (107).

6 See for the difference between manifest and occult qualities in the Middle Ages Weill-Parot (2010). Since Thorndike's (1923-1958) monumental history of magic and experimental science, occultism has been the subject of many scientific studies. See for the qualitates occultae Hutchinson (1982), Blum (1992) and Meinel (1992) as well as for Renaissance occultism Shumaker (1972), a collective volume edited by Vickers (1984), Vickers (1988), a collective volume edited by Buck (1992), Weill-Parot (2013), Saif (2015) and a collective volume edited by Classen (2017). For occultism from classical antiquity to the $20^{\text {th }}$ century see Partridge (2014). 
réciproquement selon une volute qui n'avait pas de terme, il fallait bien qu'on pensât dans le rapport du microcosme au macrocosme la garantie de ce savoir et le terme de son épanchement” $(1966,47)$ [in an episteme where signs and similarities rolled up in a volute that had no ending, it was necessary to perceive in the relationship of the microcosm to the macrocosm the guarantee of this knowledge and the end of its effusion]. Speaking of the 'relationship between magic and erudition' in early modern times, the French philosopher observes:

Le monde est couvert de signes qu'il faut déchiffrer, et ces signes, qui révèlent des ressemblances et des affinités, ne sont eux-mêmes que des formes de la similitude. Connaître sera don interpréter: aller de la marque visible à ce qui se dit à travers elle, et demeurerait, sans elle, parole muette, ensommeillée dans les choses. (Foucault 1966, 47)

[The world is covered with signs that need to be deciphered, and these signs, which reveal similarities and affinities, are themselves only forms of similarity. To know will be to interpret: to go from the visible mark to what is said through it, and without it would remain a mute word, asleep in things.]

From this perspective, the human body is susceptible to being read like a book by those who know the alphabet of physiognomy.

\section{History of physiognomy}

The Pseudo-Aristotelian Physiognomonica ( $3^{\text {rd }}$ century BC) is the oldest systematic monograph on body reading. ${ }^{7}$ Based on this treatise, physiognomy combines three methodological approaches: ${ }^{8}$ the emotional method, the ethnological method and the zoological method. ${ }^{9}$ We have news of later physiognomic work from the third pre-Christian century, by the doctor Loxus, which is lost. ${ }^{10}$ The next text that has survived is the physiognomic work of Antonius Polemon (ca. 88-145), ${ }^{11}$

7 See the edition of the text in the anthology of Förster (1893, I, 69-71) and the translations into English (Barnes 1984), Italian (Raina 1993 and Ferrini 2007), German (Vogt 1999) and Spanish (Calvo Delcán \& Martínez Manzano 1999).

8 See Armstrong (1958) and Zucker (2006, 4).

9 For the bestiary of the ancient physiognomists see Zucker (2006) and for zoomorphic comparisons in physiognomy from antiquity to the $19^{\text {th }}$ century Baltrusaitis $(1957,8-46)$.

10 See the anthology by Förster (1893, I, 1-91) and Misener (1923), Evans (1969), Boys-Stones (2007, 58-64) and Junkerjürgen (2009, 54).

11 See the edition by Hoyland (2007) and the collection of articles about this author published by Swain (2007) and particularly Swain himself (2007, 176): “The Physiognomy survives in a Greek version by Adamantius, which is undoubtedly fourth-century, and an Arabic translation 
which has come down to us in an Arabic translation from $1379,{ }^{12}$ in an abbreviated Greek paraphrase, thanks to Adamantius ${ }^{13}$ and also thanks to the so-called Latin Anonymous. ${ }^{14}$ Also preserved in a medieval manuscript was the PseudoAristotelian Secretum secretorum, ${ }^{15}$ apparently a long letter by the Greek philosopher addressed to his disciple Alexander the Great, which is actually a text from the $10^{\text {th }}$ century, the Sirr al-asrar, compiled in Syria. It is a kind of mirror of princes that brings together all kinds of knowledge, including a treatise on physiognomy. ${ }^{16}$ All these physiognomic books and their Arab continuations reached the West in the course the Middle Ages. ${ }^{17}$

(the Leiden) which exists in a single manuscript. We have also the fairly reworking of the Anonymus Latinus (including much material from Loxus and Ps.-Aristotle), which can be useful in determining Polemon's meaning in case of difficulty, and in addition the parallel Arabic versions (the Istanbul recension; hereafter TK) which are heavily reworked from the original, lost Arabic translation, but from time to time offer obvious corrections of the Leiden manuscript”.

12 See Evans (1941, 97) and Barton (1994, 102-131); for the examples used by Polemon see Mesk (1932).

13 The De Physiognomonica of Adamantius, written around 325, is - as Repath (2007, 487) notes - "essentially an abridgement of Polemon's treatise".

14 See Laurand (2005) and Repath (2007, 549-635), who comments, edits and translates the text and proposes "a date certainly beyond the middle of the third century AD and more probably somewhere near the end of the fourth" (550).

15 See Paschetto (1985, 98): “[. . . ] il Secretum non era solo un trattato di fisiognomica ma, dopo aver parlato dell'arte di governare e di questioni mediche, dedicava ampio spazio alla magia, all'astrologia ed alle scienze occulte, ivi comprese l'onomatomanzia e gli incantesimi." [The Secretum was not only a treatise on physiognomy but, after talking about the art of governing and medical matters, it devoted a great deal of space to magic, astrology and the occult sciences, including onomatomancy and spells]. For the Secretum secretorum see also the studies collected in Ryan \& Schmitt (1982) and Williams (2003), as well as the study of the Arabic and German versions of Forster (2006).

16 Williams deals with the Aristotelian spuria in the Middle Ages and questions the alleged naivety of medieval scholars with regard to works such as the Secretum: "It is easy to laugh at the schoolmen's acceptance of such patently spurious works as the widely read Secretum secretorum, the extended missive supposedly sent by the Stagirite to his former pupil Alexander the Great. In this book Aristotle gives Alexander advice on all sorts of useful occult lore, like how to fashion a powerful amulet to afflict one's enemies with fear and trembling, where to find a floating red stone that will provoke horses to neigh (thus discomfiting an opposing army), and what special ingredients to use in preparing a panacea that might have been invented by Adam himself. How could even the newly licensed arts teacher, let alone the seasoned philosopher-theologian, actually take such silliness as coming from Aristotle's pen?" $(1995,30)$; see also the section on the attribution of the Secretum (1995, 45-46).

17 See for physiognomy in the Arab World Mourad (1939), Viguera Molins (1977), Autuori (1984), Ghersetti (1994), (1995) and (1999) and Akasoy (2008), who studies physiognomy as a bridge between medicine and astrology. For translations from Arabic and the debt of European 
In the $12^{\text {th }}$ century, physiognomy was still absent from such compendia of knowledge as the Didascalion by Hugh of Saint Victor (1096-1141); ${ }^{18}$ even in the De divisione philosophiae (ca. 1145) by Dominicus Gundissalinus (ca. 1115post 1190) only chiromancy is mentioned. ${ }^{19}$ Physiognomics was reborn in the West in the $13^{\text {th }}$ century thanks to the (re)discovery of Latin, Greek and Arabic texts. Already at the beginning of the $12^{\text {th }}$ century, more precisely around $1100 /$ 1120, the work of the Latin Anonymous was discovered and began to circulate widely in the following century. ${ }^{20}$ The translation of the Liber ad Almansorem by Mohammed Rhasis $(865-925)^{21}$ by Gerardo da Cremona, ${ }^{22}$ whose second book is dedicated to physiognomy, dates from the end of the $12^{\text {th }}$ century, around 1175. Likewise, the Pseudo-Aristotelian writings with a physiognomic content are translated at that time from Arabic into Latin. There are two Latin translations of the Secretum Secretorum. ${ }^{23}$ At the beginning of the $12^{\text {th }}$ century, John of Seville made a partial translation with the title Epistola ad Alexandrum de dieta servanda (also known as Epistula Aristotelis ad Alexandrum de regimine sanitatis $)^{24}$ and at the beginning of the next one, probably before 1230 , a certain Philippus Tripolitanus ${ }^{25}$ presented a more extensive Latin text which was the

occultism to Islam see Vernet $(1999,264-269)$ and Herbers about the translation activity in Toledo: "Magische Künste wurden auch - zumindest in einigen philosophischen Schriften etwa seit dem 13. Jahrhunderts - aufgrund der Rezeption arabischer Schriften in den Kanon der Wissenschaften integriert" (1999, 246-247) [Magical arts were also integrated into the canon of sciences - at least in some philosophical writings since the $13^{\text {th }}$ century - due to the reception of Arabic texts].

18 See the bilingual edition of the Didascalicon of Muñoz Gamero \& Arribas Hernáez (2011) and Agrimi (2002, 5).

19 See the edition of De divisione philosophiae by Fidora $(2007,228)$.

20 The treaty was published under the title of De Physiognomonia liber by Rose (1864-1870, 105-139), in the anthology of Förster (1893, II, 3-145) and more recently in an Italian translation by Raina together with his edition of the Pseudo-Aristotelian Physiognomonica (1993) and by André (2003) in a bilingual French-Latin edition; see for the Latin Anonymous Rose (1864-1870, 61-102), Evans (1941, 103), Agrimi (2002, 5) and the introduction by André.

21 See for Muhammad Ibn-Zakarīyā ar-Rāzī or simply Rasi, Rhazes or Rhasis Escobar Gómez (1995) and for the reception of Rhasis by Andreas Vesalius Compier (2012).

22 This translation was published under the title of Abubecri Rasis ad regem Mansorem de re medicina liber II in the anthology by Förster (1893, II, 161-180); see Autuori (1984) and Agrimi $(2002,5)$. There are two recent editions of a $14^{\text {th }}$ century Italian volgarizzamento by Piro (2011) and Salem Elsheikh (2016).

23 See for the section on physiognomy of the Secretum secretorum Cardoner (1971, 82-85).

24 See William $(2003,31-59)$. Bizzarri $(2010,15-16)$ suspects in his edition that it was translated 'perhaps between the years 1109 and 1130, at the request of a Queen Doña Teresa, who could not be identified'. See also Pensado Figueiras (2015).

25 See Möller (1963, LVIX), William (2003, 60-108) and the edition by Bizzarri (2010, 16). 
most popular version throughout the Middle Ages. ${ }^{26}$ There were several Spanish translations in the Middle Ages: ${ }^{27}$ Poridat de las poridades, of John of Seville's version, and Secreto de los secretos, on the basis of the text by Tripolitanus, ${ }^{28}$ are followed by the Aragonese translation by Juan Fernández de Heredia $(1308 ?-1396){ }^{29}$ The second treatise, erroneously attributed to the Stagirite, the Physiognomonica, was translated in the middle of the same century by Bartolomeo da Messina from Arabic into Latin. ${ }^{30}$ Sections on physiognomy, inspired by the Greek and Arabic texts cited, would appear from now on in encyclopaedias, such as the Speculum maius (ca. 1256) by the Dominican Vincent of Beauvais (1184/1194-1264), ${ }^{31}$ and in scientific books such as De animalibus (1262-1268) by Albert the Great (1200-1280). ${ }^{32}$ Two original physiognomic treatises from the Middle Ages deserve separate mention: The Scottish scholar Michael Scott (ca. 1175-ca. 1235) wrote his Liber phisonomie (post 1228), which combines

26 See Thorndike (1923-1958, II, 267-278) and Eamon (1994, 45-46). Three Latin versions of the Secretum Secretorum are published in the Förster anthology (1893, II, 181-222). See recently the volume on the trajectory of the text in Europe by Tilliette, Bridges \& Gaullier-Bougassas (2015).

27 See for the French translations Monfrin (1964), Hunt (2000), Zamuner (2005, 50-57 and 57-60 for the Provençal), Gaullier-Bougassas (2015), Loree (2015); for the Portuguese and Catalan Zamuner (2005, 64-66 and 2005, 66-91) and for the Italian versions Cecioni (1889), Morel Fatio (1897), Franzese (1994), Zinelli (2000), Perrone (2001), Rapisarda (2001), Milani (2001), (2014) and (2015b with the edition of the physiognomic section in one of the testimonies 308-314), Zamuner (2005, 92-109) and Campopiano (2015). As for the chapters on physiognomy, Burnett notes: "Curiosamente, aunque aparecen en árabe, los apartados sobre fisiognomía y onomancia están ausentes de todas las versiones europeas del Secreto de los secretos, a excepción de la castellana and de las derivadas de ella" $(2002,133)$ [Curiously, although they appear in Arabic, the sections on physiognomy and onomance are absent from all European versions of the Secret of Secrets, with the exception of the Spanish and those derived from it]. Nonetheless, some versions discovered later include this section, such as the French version of the $15^{\text {th }}$ century, studied by Lorée (2015).

28 See for its circulation in Castile Bizzarri (1996). The Argentinian scholar suspects that the translation of the Secret is contemporary with the Siete partidas and that the Poridat may be earlier (Bizzarri 2010, 19). See for the Secreto also the edition by Jones (1995) and Bizzarri (2015) as well as for Poridat's illustrations Cacho Blecua (2016).

29 See Val Naval (2002).

30 See the text in the anthology by Förster (1893, I, 4-92) and in the recent critical edition by Devriese (2019).

31 Since there is no modern edition of this medieval encyclopaedia, we must go to the incunabulum editions as Speculum Naturale, Venice, Hermann Liechtenstein, 1494, available online http://daten.digitale-sammlungen.de/ db/0005/bsb00056560/images/ (visited on 29.5.2020).

32 See Agrimi (2002, 8). 
physiognomics with the theory of complexions at the court of Frederick II. ${ }^{33}$ Peter of Abano (ca. 1250-1316), ${ }^{34}$ a Paduan doctor based in Paris, studies body signs in relation to astrology in his Compilatio Physionomie (1295). ${ }^{35}$

\subsection{Physiognomy in print}

The ancient and medieval physiognomies were given new life in print: the first physiognomic study to be printed was the Liber compilationis phisonomie by Peter of Abano in 1474. The Scottish scholar's Liber phisonomiae was published repeatedly from the princeps edition (Venice, Jacopo da Fivizzano, 1477). The first vernacular translation of this treatise is to Spanish; it appeared without mentioning Scott's name in the Compendio de la salud humana (1494 and 1495). ${ }^{36}$ That this compendium was almost a bestseller can be gathered from the fact that, well into the $16^{\text {th }}$ century, the book was republished by the Cromberger, who used to have a nose for sales. In addition to the presence of annotated copies in current Spanish libraries and in the inventories of wills of the time, the continued interest in Michael Scott is reflected in the rewriting of his physiognomic theories in other publications such as, for example, the Libro de phisonomia natural y varios secretos de naturaleza (1598) by Jerónimo Cortés.

The physiognomic studies of classical antiquity and, first of all, those works still attributed to the Stagirite were of great interest to humanists and, above all, to physicians with Hellenistic training who tried to produce reliable editions from the Greek originals, much to the detriment of the Arab tradition, considered to be corrupt. Actually, some editions tell us eloquently how these PseudoAristotelian works were read and studied in early modern times. The printed diffusion of the work of the Peripatetic is closely linked to the Aristotelianism of the Renaissance universities and particularly to the so-called school of Padua.

33 There is a modern edition of the Latin text with an Italian translation by Porsia (2009) and a Latin edition by Voskoboynikov (2019); see for Scott's Liber phisonomiae Damiani (1974), Jacquart (1994), Agrimi (2002, 5 and 22-29) and Ziegler (2008). As for Michael's sources see Burnett $(1994,109)$.

34 There is no modern edition of the Compilatio Physionomie; see for Peter of Abano's physiognomy Paschetto (1984, 139-150) and (1985) and Jacquart (1993) and (2013).

35 See in this regard Paschetto $(1985,106)$, Federici Vescovini $(1991,45)$ and Porter $(2005,73)$. 36 The Spanish version was edited by Sánchez González de Herrero \& Vázquez de Benito (2009). 
From 1482 the Physiognomonica was included, in Bartolomeo da Messina's translation, in some Latin editions of the complete works of the Stagirite, while as Schmitt observes- the Secretum "never appeared in a Latin edition of the Opera" (1982, 125). Between 1495 and 1498 Aldo Manuzio published a major folio edition of Aristotle in Greek, which includes, in the third of its five volumes, the Physiognomonica. The existence of the Greek original allows the philological recovery of the text. The Secretum secretorum, on the other hand, belongs to the second of the two categories of spuria established by Schmitt: he distinguishes "those coming from a Greek original and those for which there was never a Greek text" (1982, 124). Although these texts were of little interest to humanist philologists, the Secretum Secretorum had an enormous diffusion printed from the editio princeps (Cologne, Arnold ter Hoernen around 1475) in the translation of Philippus Tripolitanus. As Kraye observes, “[t]he Secret of Secrets was published together with a number of different texts - plague tracts, medieval preaching aids, astrological and magical treatises concerned with medicine [. . . ] - but it did not appear in the company of any genuine Aristotelian work" (1995, 208-209). One of these books was no other than Michael Scott's Physiognomy in the 1484 edition, which came out of Johann Veldener's presses in Leuven. Two Latin editions of the Secret of Secrets are currently published in Spain, but neither of the medieval Castilian versions (Poridat de las poridades or Secreto de los secretos) sees the light of day in print. However, the text circulates in printed form in Italian, German, English and especially in French. As Kraye remarks, incunabula editions - in Latin and French - do not usually disseminate the full text and often combine abridged versions with other works of various kinds. Silvi rightly remarks that "ce qui parait caractériser ce traité, c'est une sorte d'instabilité chronique, une mouvance qui se vérifie tant au niveau du texte que du paratexte qui l'entoure et des autres textes auxquels il se trouve, parfois, associé" $(2015,158)$ [what seems to characterise this treatise is a kind of chronic instability, a movement that is evident both in the text and in the paratext that accompanies it and in the other texts with which it is sometimes associated]. According to the aforementioned French researcher, the printing press divulges the Secret of Secrets as "ouvrage d'édification politique et moral" $(2015,174)$ [work of political and moral edification]. Williams, who underlines the use of the treatise as speculum principis, remembers that "the Secretum continued to be offered to rulers into the Early Modern era: to Henry VIII and Edward VI of England in the $16^{\text {th }}$ century; to Philip IV of Spain in the $17^{\text {th }}$ century" (2004, 141).

The new translations of the Pseudo-Aristotelian Physiognomonica published in the 1530s are in turn part of the trend of medical humanism that applies philological tools to scientific literature in the Greek language. It is striking that a few years after Andrés Laguna's translation, another physician dedicated himself to the 
recovery of the same text, the German Jodocus Willich (1501-1552), a friend of Melanchthon, who, in 1538, published the Latin Physiognomonica Aristotelis (Wittenberg, Nickel Schirlentz). While the Physiognomonica continues to be published, in Bartolomeo da Messina's translation, and remains a subject of study even in the $17^{\text {th }}$ century, the Secreta Secretorum was last published in Latin in 1555 along with a whole series of other texts.

Polemon's work ${ }^{37}$ was first published in the original Greek together with those of Adamantius and other divinatory texts as an appendix to the Various Histories of Aelianus in 1545. The first Latin translation of Polemon, by Nicholas Petreius (1486-1568), a native of Corfu, was issued in 1552 accompanied by other unpublished Greek texts on the human body like Melampus' De neuis corporis. The first translation of Polemon into a vernacular language is a Spanish one printed at the end of the $16^{\text {th }}$ century in Milan, followed by an Italian version of 1612 made by the sixteen-year-old Francesco Montecuccoli, whose brother Carlo had submitted a new Latin translation the same year.

The story of Adamantius' print transmission is much more complex. ${ }^{38}$ The Greek original was published on its own prior to Polemon's work in France in 1540 and four years later in a bilingual Latin-Greek edition by the German Hellenist physician Janus Cornarius (1500-1558) along with other texts. Another Latin translation was provided by Pomponio Gaurico (ca. 1484-1530) in 1551. ${ }^{39}$ Later on, well into the $17^{\text {th }}$ century, a French translation was published, made by another precocious young man: the twelve-year-old Henry de Boyvin du Vauroüy dedicated his La physionomie of 1635 to none other than Richelieu.

The physiognomic theories of Polemon and Adamantius, as well as those of Aristotle and the lost work of Loxus, are also disseminated through the treatise of the so-called Anonymous Latin. This physiognomic work, De Physiognomonia liber, was published under the title of De diversa hominum natura, (Lyon, Jean de Tournes, 1549) by Antoine Du Moulin (ca. 1520-1580).

In the dedication of his French translation of Artemidorus, the humanist Charles Fontaine observes: "Aussi de ce temps heureux du Roy Françoys [...] nous avons l'art de Phisionomie, Chiromance, Astrologie mieulx et plus correctement imprimé, que depuis cinq cent ans. Et par son autorité et commandement

37 See the collection of articles on this author published by Swain (2007) along with editions and translations of his physiognomic works. For occurences of the name in a corrupted way in the Italian translation of the Secretum secretorum see Milani (2015a).

38 Consult for this author and the transmission of his work Förster (1897, 298-299) and Repath (2007, 487-548).

39 See for Gaurico as physiognomist Vigh (2014, 171-202). 
nous voyons toutes sciences se resjouyr, et renouveller" ${ }^{40}$ [From the fortunate times of king Francis I . . . we have the art of physiognomics, palm reading and astrology better and more properly printed than in the 500 years before. And because of his authority and command we see all sciences flourish and revive].

The $15^{\text {th }}$ and $16^{\text {th }}$ centuries saw the appearance of new manuals and treatises specialising in physiognomy and related subjects, such as metoposcopy or chiromancy, which are in part commentaries on the classical texts or re-editions of. As Porter points out, these publications attracted the interest of a large number of readers from all strata of society:

They were published in all formats, from cheap, ephemeral single-sheet pamphlets to the most lavishly illustrated, hand-painted vellum or leather bound folios, and distributed across Europe and later to America, far beyond the main printing centres of Europe's urban growths, to a reading and listening audience made up of a wide range of ages, sexes, occupations, and incomes. (2005, vii)

At the beginning of the $16^{\text {th }}$ century, Alessandro Achillini's De Chyromantiae principiis et physionomiae (Giovanni Antonio de Benedictis, 1503) was published in Bologna. ${ }^{41}$ The Bolognese professor had conceived this text, which is significantly presented as a quaestio, as an introduction to the physiognomic and chiromantic work of his student Bartolomeo della Rocca, ${ }^{42}$ known by the nickname of "Cocles" (Chyromantie ac physionomie anastasis cum approbatione Alexandri de Achilinis, Bologna, Giovanni Antonio Benedetti, 1504). His intention was to claim the scientific status of this semiotic practice. We know very little about the aforementioned Cocles. ${ }^{43}$ He seems to have been a kind of itinerant fortune teller who was regularly expelled from the small courts of the Romagna for predicting some kind of infamous death to the powerful; having

40 Fontaine, Dédicace à quelque personnage d'authorité $(1546,6)$.

41 See Zambelli (1978, 59-86), Matsen (1974 and 1975, 437-451) and Porter (2005, 20 and 53).

42 For the relationship between Achillini and Cocles see Porter (2005, 154-155).

43 The few known data from Cocles' biography are extracted by Zambelli (1978, 79-81) from the works of Girolamo Cardano, Luca Gaurico and a certain Orazio Bicarti; also see Zaccaria (1989). González Manjarrés $(2015,169)$ argues: "Su biografía es un caso prototípico: consideraba que el dominio de la fisiognomía y la quiromancia servía para conocer de verdad a los demás, para prever su conducta e incluso para adivinar los acontecimientos futuros, y así llegó a tener un gran prestigio y una importante clientela por su habilidad de fisiognomista y quiromántico, hasta que murió asesinado unos días después de la publicación de su obra" [His biography is a prototypical case: he considered that the mastery of physiognomy and chiromancy served to really know others, to foresee their behaviour and even to guess future events, and thus he came to have great prestige and an important clientele for his ability as a physiognomist and chiromancer, until he was murdered a few days after the publication of his work]. 
done so with Ermete Bentivoglio cost him his own life on September 24, 1504 at the hands of a hired assassin paid by the heir to the lordship of Bologna. ${ }^{44}$ Cocles' work seems to have been an important sales success, judging by the number of publications circulating today under his name, although they may have nothing to do with him. In 1510, the printer Johann Schönsperger published his first book in Augsburg under the title of In disem biechlin wirt erfunden von Complexion der Menschen zu erlernen leiblich und menschlich natur ir sitten, geberden und naiglichait zu erkennen und urtaylen. Although Cocles' name does not appear on the cover, nor in the prologue or in the colophon, the work is usually attributed to him. ${ }^{45}$ As Duntze $(2007,134)$ rightly notes, this Complexionsbüchlein is not an extract of the Chyromantie ac physionomie anastasis but a compilation of the physiognomic theories of Secretum secretorum and those of Michael Scott, which were enormously successful in Germany. In 1530, the printer Christian Egenolf changed the title of the booklet and explicitly attributed it to Cocles: Phisonomei. Eins jeden Menschen Art, Natur und Complexion aus Formierung und Gestalt des Angesichts, Glieder und allen geberden zu erlernen. Bartholomeus Coclitus von Bononien. This publicity stunt explains the attribution of the text and has misled its readers until today. When Johann Albrecht, a printer in Strasbourg, translated the text from German into Latin, along with Egenolf's new foreword, it was a good idea to attribute the work to a doctor and philosopher to give it an air of seriousness. It also adds 15 engravings that illustrate the physiognomic part and that follow the same scheme as those used in the book by Ioannes ab Indagine.

Johann Albrecht's compilation was translated into French and published in 1546 with the same illustrations and under the title of Le compendion et brief enseignement de physiognomie \& chiromancie (Paris, Pierre Drouard). The text was republished by the same printer only three years later, in 1550 and 1560, as well as on several other occasions in the $16^{\text {th }}$ and $17^{\text {th }}$ centuries.

A very different diffusion was to have the text that in 1521 the printer Johann Schott published in Strasbourg, the Introductiones apotelesmaticae elegantes in chiromantiam, physionomiam, astrologiam naturalem by Ioannes ab Indagine, reedited in 1522, 1531, 1534 and in 1541 with a larger number of engravings and, already in 1523, in a German translation with the same graphic material. The Latin text continued to be republished in the $16^{\text {th }}$ century in Germany and also, and above all, in France. It was translated into French by Antoine de Moulin, editor and translator of Adamantius, in 1549. The illustrations in the Lyon edition were made by

44 Porter $(2005,155)$.

45 See Reißer (1997, 56-61), Reske (2007, 32). 
the engraver of Jean de Tournes, Bernard Salomon (ca. 1508-ca. 1561), who was inspired - according to Sharratt $(2005,78)$ - by the Cocles editions. The first reprint of Indagine's publications in the $17^{\text {th }}$ century was published in 1603 in Germany, in Oberursel to be precise, by the Lutheran printer Cornelius Sutor, together with the texts of two other problematic authors, Guglielmo Gratarolo and Pomponio Gaurico. Indagine's work was prohibited by the Spanish indexes of 1559 and $1583 .{ }^{46}$ In the Index Expurgatorius Hispanus (1707) of Sarmiento y Valladares, Indagine is still listed as a first-class author. ${ }^{47}$

In the middle of the century some original, less known treatises on the meaning of the human body were also printed: De cognitione hominis per aspectum (Rome, Antonio Blado, 1544) by the physician Michelangelo Biondo, editor of Peter of Abano, ${ }^{48}$ as well as a dialogue on I Segni de la natura ne l'huomo (Venice, Giovanni de Farri et fratelli, 1545$)^{49}$ by the physician Antonio Pellegrini, author of the Italian translation of the Encomium Moriae (Venice, Giovanni della Chiesa, 1539)., ${ }^{50}$ A long chapter on physiognomy is also found in the onomantic

46 Bujanda (1984, V, 394). The Index of 1583 prohibits all works by the German author, see Bujanda (1993, VI, 404); see for banning in the $17^{\text {th }}$ and $18^{\text {th }}$ centuries Bujanda \& Richter (2016, 675).

47 In the indexes of banned books, first-class authors, also called of damnatae memoria, are authors whose complete works are banned a priori. In the case of authors of scientific works this condemnation may be due to other publications of theirs, especially theological ones, see Pardo Tomás $(1991,118)$.

48 There is a modern bilingual Latin-Italian edition by Rodler (1995). As the editor notes in her "Introduzione", Biondo's work was distinguished by a "costante volontà di riduzione divulgativa" (1995, 13) [constant desire for a reduction for the purpose of popularisation]. According to Wilson, Biondo's work is "a reflection on the social value of physiognomy and the moral questions that accompany external appearances” $(2011,181)$.

49 See the concise summary in Wilson $(2011,181)$, who underscores that the text "brings together the dialogue format of courtesy books with the indexing of facial features, types, and emotions that characterises physiognomy treatises. On the first day, Alessandro Dolce encounters the English ambassador and the Spanish consul at Murano where they talk about affects and inclinations based on the body's disposition. They reconvene the second day at Dolce's house, when they are joined by other Venetians - a doctor, a philosopher, and a theologian with whom they debate the signs of human nature. As Pellegrini explains at the beginning of the tract, the delight men take in learning about the differences between each other enables men to understand themselves".

50 See Bennett, who notes regarding the relationship between the translation of Moria and the physiognomic study: "In I Segni de la Natura Pellegrini attempts to understand man before all other creatures because self-knowledge was recommended by the ancients [. . .] This study of physical and psychological features is not a surprising sequel to Pellegrini's translation of the Moria where he is most interested in the nature of man as fool" $(1984,41)$. Likewise, Seidel Menchi relates the dedication to occultism with Erasmism: "L'attaccamento ai libri di Erasmo 
study by the Veronese doctor Annibale Raimondo (1505-1591). After the middle of the century, the Belgian musician, astrologer and mathematician Jean Taisnier (1508-1562) in 1562 published an extensive physiognomic and chiromantic work in Cologne, titled Opus mathematicum octo libros complectens: innumeris propemodum figuris idealibus manuum et physiognomiae. Several copies of the first edition of 1562 are preserved in Spain, two in the National Library of Madrid and another in the Marqués de Valdecilla Historical Library of the Complutense University (BH FLL 14738). This copy was expurgated by Friar Hieronymus Lucas de Alaejos, the senior librarian of the El Escorial Library, who was in charge of selling the duplicate books from the library of Philip II. ${ }^{51}$ In spite of this evident censorial intervention in the book, Taisnier was not sanctioned in the Spanish indexes nor in the expurgatory of 1707 . However, it was a dangerous book for its owners. In 1583, a certain Pedro Suárez de Mayorga, a supporter of chiromancy, was denounced in New Spain for his possession of the Taisnerio. ${ }^{52}$

The pre-Lavarian physiognomist par excellence ${ }^{53}$ is the Neapolitan natural philosopher Giovanni Battista Della Porta (1535-1615), ${ }^{54}$ renowned throughout Europe ${ }^{55} \mathrm{He}$ is the author of several physiognomic studies, published in Latin and Italian, although his best known book is Magia naturalis (1558), ${ }^{56}$ which is his only

si associa [. . .] alla lettura di opere di filosofia occulta, particolarmente al trattato De occulta philosophia di Agrippa di Nettesheim. Da questo punto di vista le vicende che illustreremo sono solo un campione di una casistica più vasta, nella quale rientrano per esempio il caso di Paolo Cataldi o la parabola di Antonio Pellegrini, traduttore dell'Encomium moriae, che proseguì la sua attività letteraria con un'opera di fisiognomica." (1987, 291) [The attachment to the books of Erasmus is associated . . . with the reading of works of occult philosophy, particularly the treatise De occulta philosophia by Agrippa of Nettesheim. From this point of view, the events we will illustrate are only a sample of a larger case history, which includes for example the case of Paolo Cataldi or the parable of Antonio Pellegrini, translator of the Encomium moriae, who continued his literary activity with a work of physiognomy.] For the translation of Erasmus in the European context see Ledo \& Boer in their edition of the Spanish translation $(2014,11)$.

51 See Gernert (2014b) and (2018a).

52 See Jiménez Rueda (1946, 220-221) and Caro Baroja (1990, II, 300, footnote 21).

53 See Macdonald (2005, 397-414).

54 Regarding the influence of the scientific and cultural environment of Naples on Giovanni Battista and his brother, see Badaloni (1960).

55 Simon, who studies the methodology of the Neapolitan, characterises him as "ami de Giordano Bruno, inspirateur de Kepler en optique, lu par Descartes” $(1980,96)$ [friend of Giordano Bruno, Kepler's inspiration in optics, read by Descartes].

56 There are translations into Italian (1560), French (1565), Dutch (1566) and later also into German (1612) and English (1658); Balbiani (2001) and the collective volume edited by Zeller (2008). For the reception of the book in Spain see Rojo Vega $(2008,283)$. 
publication sanctioned in Spain and included in the 1583 Quiroga index ${ }^{57}$ as well as in the expurgatory of Valladares and Sarmiento (1707). In his own country, the Neapolitan philosopher had serious problems with the Inquisition. In the case of De humana physiognomonia ${ }^{58}$ the desired imprimatur takes three years to arrive. When he finally published the book, in 1586, he added a paratext in which he defended himself against accusations of determinism. When Della Porta wanted to publish the Italian translation of the new version of De humana physiognomia, he had to turn to the influential Roman nobleman Federico Cesi, who got him permission from the Roman Inquisition in $1610 .^{59}$ This treatise, which gathers much of the previous physiognomic knowledge, ${ }^{60}$ highlights in the text and illustrations the comparisons between human beings and animals. ${ }^{61}$ Della Porta's method is

57 In addition to the classic work of Reusch (1883-1885), the most recent publication of the Indexes by Bujanda is fundamental, particularly the volumes dedicated to the Spanish Inquisition (1984, V) and (1993, VI, 393-394 and 456). In spite of these condemnations we have evidence of the presence of the work in Spain.

58 There is a critical edition of Paolella (2011) and (2013) that summarises in its introduction the complicated history of the publication of the Latin and Italian texts (XI-XXIV); see also the study by Verardi (2011a) and for the presence of classical poets in this work González Manjarrés (2010).

59 See Piccari (2007, 43-44); for Della Porta's relations with Cesi, a founding member of the Accademia dei Lincei, see Gabrieli (1927).

60 See Bouchet (1957, 20-21) and González Manjarrés (2016, 71); Basile (2016, 58) rightly speaks of the 'encyclopedic completeness' of the work.

61 "La pretensión de Della Porta era confeccionar, con intención pedagógica, una suerte de manual que al tiempo sistematizase y sintetizase todos los conocimientos y métodos fisiognómicos que han ido acumulándose a lo largo de los siglos. Su lectura recuerda a un almanaque o collage compuesto de numerosos grabados y citas fisiognómicas, médicas, filosóficas, literarias y biográficas articuladas según un plan preciso and ordenadas bajo su criterio.” (Lozano Pascual 2009, 209) [Della Porta’s aim was to produce, with a pedagogical intention, a kind of manual that would systematise and synthesise all the knowledge and physiognomic methods that had been accumulated over the centuries. Its reading is reminiscent of an almanac or collage composed of numerous physiognomic, medical, philosophical, literary and biographical engravings and quotations articulated according to a precise plan and ordered according to his criteria]. See for the Pseudo-Aristotelian background of animal parallels Muratori (2017). González Manjarrés (2016) studies the 'critical notes' of Della Porta to the Pseudo-Aristotle while Vigh devotes himself to the "impostazione morale prevalentemente aristotelica nella descrizione dei vizi, delle virtù e dei comportamenti" $(2016,113)$ [predominantly Aristotelian moral approach in the description of vices, virtues and behaviour]. For authorship and sources of the illustrations see Paolella (2016) and for repeated use of the engravings Schmidt (2007, 286-287). 
not based exclusively on bookish knowledge but makes use of empirical data and observation. ${ }^{62}$ The merit of the Neapolitan consists in having separated physiognomy from astrology. ${ }^{63}$ Despite problems of censorship, Della Porta's books were read throughout Europe in a large number of reprints until the second half of the $17^{\text {th }}$ century.

It was possibly the success of the physiognomic work and the research by Giovanni Battista Della Porta which spurred the emergence of studies of bodily signs of various kinds that were published in the 80 s and 90 s of the $16^{\text {th }}$ century, even after the bull Coeli et Terrae Creator, in which, in 1586, Pope Sixtus V prohibited the exercise of judicial astrology and other forms of divination.

The spread of physiognomic knowledge in the Iberian Peninsula was due, from the end of the $16^{\text {th }}$ century until well into the $19^{\text {th }}$ century, to one man of whom we know very little. I am referring to Jerónimo Cortés, author of a Libro de phisonomia natural y varios secretos de naturaleza (Valencia, Garriz, 1599). ${ }^{64}$ This is the first physiognomic manual written directly in Spanish, although a large part of its materials come from Michael Scott; together with him, they are cited as sources in the prologue "Tisnerio [. . . ] y Pedro de Ribas".

62 See in this regard the study of the structure of the physiognomic sign in Della Porta of Caputo, who concludes: "In conclusione si può dire che la cultura, l'umanesimo, il neoplatonismo di Giovambattista Della Porta vengono filtrati tramite una competenza logica aristotelica che costituisce il sostrato del suo pensiero. Egli non è un logico ma uno scienziato la cui attività scientifica à consona alle nuove esigenze sociali, antiaccademica, antiaristocratica, antidogmatica per scoprire quale sia il fondamento naturale dei fenomeni osservati e raccontati” (1982, 102) [In conclusion, it can be said that Giovambattista Della Porta's culture, humanism and Neoplatonism are filtered through an Aristotelian logical competence that constitutes the substratum of his thought. He is not a logician but a scientist whose scientific activity is consonant with the new social, anti-academic, anti-aristocratic, anti-dogmatic needs in order to discover the natural foundation of the observed and narrated phenomena].

63 Trabucco $(2002,47)$. Verardi $(2008,83)$ explains this decision with the Papal Bulls against divinatory practices: "Contribuiscono, poi, alla trasformazione della disciplina fisiognomica anche alcuni eventi storici, ultimo fra tutti la presa di distanza di Sisto V dalle pratiche astrologiche, che spinsero il più grande fisionomo del Rinascimento, Giovanni Battista Della Porta, a liberare la proprio filosofia da qualsiasi residuo astrologico.” [Some historical events also contributed to the transformation of the discipline of physiognomy, the most recent of which was the distancing of Sixtus $V$ from astrological practices, which pushed the greatest Renaissance physiognomist, Giovanni Battista Della Porta, to free his philosophy from any astrological residue].

64 ee the electronic edition curated by Saguar, which provides readers with a database of all the editions and the copies preserved in each of them: http://hispanistik.uni-trier.de/v-machine/ JeronimoCortes/FisonomiaNatural.xml (visited on 14.6.2020). 
In Spain there is also evidence of a Historia de animales y phisiognomia by a certain Luis Fernández, a physician from Carrión de los Condes, dedicated to the Marquise of Fromista. This $16^{\text {th }}$ century text, still unpublished, obtained the license to be printed in $1591 .^{65}$

In the first half of the $17^{\text {th }}$ century, a large number of reprints of previous physiognomic studies appeared, mainly by Jerónimo Cortés, but also, although to a lesser extent, by Girolamo Manfredi (1600, 1607, 1629), Johannes ab Indagine (in Latin and French translation 1603, 1604, 1621, 1622, 1638) and Giovanni Battista Della Porta, together with those of lesser-known authors such as Antonio Pellegrini (1622). But in addition to the reprints, which testify to the great interest in the subject, new texts continue to appear, which in many cases are presented, from the very title, as continuations of Aristotelian principles. While in Italy, France and Germany a multitude of very different texts are printed, in Spain, after Cortés, only one other treatise, El sol solo y para todos sol de la Filosofía sagaz y anatomía de ingenios by Esteban Pujasol was published. ${ }^{66}$ We have little news about this Aragonese priest, a native of Fraga, who was attracted by the subject in spite of its delicate nature for the ecclesiastical authorities. Pujasol's physiognomic work, which researchers often relate to the Examen de ingenios of Huarte de San Juan, ${ }^{67}$ is in part a reduction of Della Porta as Cardoner $(1971,90)$ has shown.

After the 1660s, no new physiognomic studies were published, but the works of Cocles (1679, 1698, 1700), Indagine (1662, 1663, 1672, 1682), Della Porta $(1668,1677)$ and Cortés $(1662,1664,1675,1680,1681,1689,1695,1701)^{68}$ were still being reprinted, in addition to the reissues of the texts from the first half of the century. Courtine insists on the continuity of the physiognomic treatises of the first half of the $17^{\text {th }}$ century with the previous tradition:

Jusqu'aux années 1660 environ se multiplient les traités qui reprennent imperturbablement les mêmes leçons antiques, accompagnés de nombreuses 'métoposcopies', ces traités de divination astrologique qui vont offrir aux lecteurs de l'âge classique des interprétations des marques gravées par les planètes sur le front des humains. C'est dire que la tradition physiognomonique est dominée dans les deux premiers tiers du XVII ${ }^{\mathrm{e}}$

65 The manuscript is preserved in the Library of Menéndez Pelayo (sign M. 243) Riandière La Roche (1990), who provides a detailed description of the content, promising an edition of the text, which, however, has not yet been published.

66 There is a modern edition (1980) with a brief introduction and another facsimile edition (2000) without paratext.

67 See Ibarz (1991) and Ricarte Bescós (2008, 58-60).

68 For a complete list of the editions of Cortés' book, see the electronic edition of Saguar: http:// hispanistik.uni-trier.de/v-machine/JeronimoCortes/FisonomiaNatural.xml (visited on 14.6.2020). 
siècle par une pensée et une perception analogique du corps humain, conforme aux théories des signatures héritées des philosophies de la nature du moyen âge et de la renaissance. $(1995,50)$

[Until about the 1660s, treaties multiplied, which invariably repeated the same ancient lessons, accompanied by numerous 'metoposcopies', those astrological divination treatises that would offer readers of the classical age interpretations of the marks engraved by the planets on the foreheads of humans. In other words, the physiognomic tradition was dominated in the first two thirds of the $17^{\text {th }}$ century by an analogical thought and perception of the human body, in line with the signature theories inherited from the nature philosophies of the Middle Ages and the Renaissance.]

According to Porter, physiognomy ceased to be a form of knowledge at this time and became more and more "simply a laughable, if amusing, game" $(2005,18)$. For Wilson this "ludic turn might be understood as a symptom of anxiety wrought by the double bind of the politics of faciality, of the need for faces to conform on the one hand, and their failure, on the other, to be meaningful any longer" $(2011,187)$.

\section{The interpretation of the hand}

Chiromancy and metoposcopy are disciplines closely linked to physiognomy and therefore there are many treatises dealing with both disciplines. ${ }^{69}$ It is therefore not surprising that, in printed transmission, physiognomy shared spaces and readers with palmistry, metoposcopy and other divinatory arts such as judicial astrology, geomancy or onirocriticism, among many others. Since Alessandro Achillini (De Chyromantiae principiis et physionomiae, 1503) and Bartolomeo della Rocca, "Cocles" (Chyromantie ac physionomie anastasis) the convergence of both semiotic practices is highlighted in the title of the publications as is the case in the texts of Ioannes ab Indagine (Introductiones apotelesmaticae elegantes in chiromantiam, physionomiam, astrologiam naturalem, 1521) and Jean Taisnier (Opus mathematicum octo libros complectens: innumeris propemodum figuris idealibus manuum et physiognomiae, 1562) in the $16^{\text {th }}$ century. In the following century, Christian Moldenarius, Jean Belot (Instruction familière et très facile pour apprendre les sciences de chiromance \& phisiognomie, 1619) and Sieur de Peruchio (La chiromance, la physiognomie et la geomance, 1657) continued along this path; other authors, however, preferred to keep them separate, as for example Cureau de la

69 See Poma $(2010,118)$. 
Chambre, who published two single treatises containing chiromantic (Discours sur les principes de la chiromance, 1653) and physiognomic (L'Art de connoistre les hommes, 1659) reflections.

Palmreading, like physiognomy, had been known since classical antiquity, ${ }^{70}$ although it does not seem to have been very widespread and important. ${ }^{71}$ An observation by Aristotle in his Historia animalium I.12.493b32 about the meaning of the lines of the hand "added a certain respectability to the subject" (Burnett $1987,192){ }^{72}$ Although no classical treatise has survived, early medieval palmistry relies on the authority of the Stagirite.

In Latin the earliest separate treatment of chiromancy as a distinct subject, art or science, appears to have been in translation from the Arabic - albeit somewhat dubiously - ascribed to Adelard of Bath and John of Seville of the twelfth century. In both cases Aristotle is sometimes named as the original author. (Thorndike 1965, 674) (33 $^{73}$

The oldest recorded text is found in the so-called Eadwine Psalter of the $12^{\text {th }}$ century; ${ }^{74}$ around that same time we find the first references to palmistry ${ }^{75}$ in the $D e$

70 Burnett $(1987,192)$ mentions references in Artemidorus, Pollux and Suidas. Rapisarda notes, conversely, in the "Introduzione" in Rapisarda \& Piccione (2005, 20): "Non c'è alcuna prova che la cultura classica abbia praticato, almeno in forma sistematica, questa tecnica divinatoria e nessuna menzione se ne ritrova, nell'Occidente latino, in testi che siano anteriori al 1150. È nella cultura tardo-greca, imperiale e bizantina, che se ne cominciano a trovare occasionali citazioni, come in Artemidoro, in Polluce (II secolo d. C.) e nel lessico Suda (X secolo d. C.), insieme a qualche frammento papiraceo di testo scritto" [There is no evidence that classical culture has practised, at least in a systematic way, this divinatory technique and no mention of it can be found, in the Latin West, in texts dating back to before 1150. It is in the late Greek, imperial and Byzantine culture that occasional references to it are beginning to be found, as in Artemidorus, Pollux ( $2^{\text {nd }}$ century A.D.) and in the lexicographer Suidas $\left(10^{\text {th }}\right.$ century A.D.), together with a few papyrus fragments of written text]. See also Tuczay $(2012,101)$ and Castelli (2006, 495-496).

71 Palmistry is not listed among the practices that Cicero refutes in De divinatione, see the Latin edition with German translation by Schäublin (1991) and the Spanish edition by Escobar (1999) with the respective paratexts.

72 See Rapisarda in the "Introduzione" in Rapisarda \& Piccione $(2005,15)$.

73 See for the authorship of medieval chiromancy and the attributions to Aristotle Pack (1969, 189), Schmitt \& Knox (1985, 21-24) and Rapisarda in the "Introduzione" in Rapisarda \& Piccione $(2005,23-24)$ as well as Fürbeth's $(2003,103)$ observations. See also Sabattini's (1946) catalogue of chiromantic works.

74 The text was published by Burnett (1987) and with an Italian translation by Rapisarda \& Piccione (2005, 61-76); see Rapisarda in the "Introduzione" in Rapisarda \& Piccione (2005, 22-23) and the studies on this psalter published by Gibson, Heslop \& Pfaff (1992).

75 Fürbeth $(2003,101)$. 
divisione philosophiae (ca. 1145) by Dominicus Gundissalinus (ca. 1115-post 1190) ${ }^{76}$ and in the Policraticus (ca. 1159) by John of Salisbury (1115-1180), which defines palmists as those who by a reading of the lines of the hand predict unknown events. Even Thomas of Canterbury (1118-1170) could not escape temptation and was probably one of the first famous clients of these soothsayers. ${ }^{77}$

In the Middle Ages there was a whole series of treatises on the art of interpreting the lines of the hand that have been published in our time by Rapisardi and Piccione (2005). ${ }^{78}$ As is usual in all disciplines at the beginning of the modern world, the knowledge previously written in manuscript was transmitted by the printing press; as a matter of fact, some of the medieval chiromantic manuals were already published in the period of incunabula in Germany and Italy, with engravings that show the different lines and mountains of the hand. The most successful $15^{\text {th }}$ century chiromantic manual outside its country of origin was that of Andrea Corvo de Mirandola. Its spread at the beginning of the $16^{\text {th }}$ century is documented by very early translations into French, German, Italian and Spanish. ${ }^{79}$ On occasion, Corvo's handbook on palm reading was printed together with the chiromantic and physiognomic texts attributed to Bartolomeo della Rocca. The work of Cocles, which combined in print the studies on physiognomy and palmistry for the first time were commented by Patrizio Tricasso Cerasari in a treatise that was published almost simultaneously in Latin and Italian (Super Chyromantiam Coclytis dillucidationes and Expositione del Tricasso Mantuano sopra il Cocle, both Venice, Elisabetta Rusconi, 1525). Tricasso had previously gained a reputation as a palmist with a treatise that was still sold in French translation still in the $17^{\text {th }}$ century. The presence of Patrizio Tricasso da Cerasari in Spain and the problematic status of the author is documented thanks to the spectacular discovery of the hidden books in Barcarrota; ${ }^{80}$ in the walled-in hideout two of his chiromantic publications were found, one in Latin and the other in Italian, ${ }^{81}$ which must have been considered by their owner to be just as

76 See the chapter De astronomia, in which Dominicus Gundissalinus speaks of various divinatory arts, De divisione philosophiae, ed. Fidora (2007, 228), studied by Agrimi (2002, 5 and nota 8); see regarding Gundissalinus and science Fidora (2003, Spanish translation 2009, 108 for palm reading), (2011) and (2013).

77 See Rapisarda in the "Introduzione” in Rapisarda \& Piccione (2005, 11), Boudet (2006, 100-101) and Castelli (2006, 496).

78 See Pack (1969), (1972), Pack \& Hamilton (1971) and Burnett (1987).

79 The Spanish text was edited by de Páiz Hernández (2006).

80 See Gernert (2014b, 105-106) and, on the question of whether the owner of the library was a converted Jewish bookseller or physician, Rico (2000) and Serrano Mangas (2004) and (2007). 81 See Lama (2007), Sánchez Salor (1999 and 2007), Gernert (2014b) and the edition of the text by Sánchez Salor \& Ruiz García (2000). 
compromising as the work of Erasmus or the obscene Cazzaria. However, the Spanish indexes did not explicitly forbid Tricasso's chiromantic studies, which were, nevertheless, condemned by the Roman indices of 1559 and $1596 .^{82}$

Another specialist in chiromancy and divinatory arts of the $15^{\text {th }}$ century was Antioco Tiberto. The author, a practising palmist, was executed by Pandolfo Malatesta because he had predicted him exile and poverty. ${ }^{83}$ His only known book is the Chiromantia (Bologna, Benedetto Faelli, 1494) which was republished twice by Johannes Dryander (i.e. Juan Enzinas) with dedications to the jurist Johannes Furderer von Richtenfels and the archbishop of Mainz Albrecht von Brandenburg (1490-1545), one of Luther's most popular antagonists.

In Italy we also find the physician and philosopher Galeotto Marzio da Narni (ca. 1425-ca. 1494), ${ }^{84}$ author of a Chiromantia perfecta, written around 1490. In this treatise, he tries to invalidate the criticism of St Thomas' chiromancy by arguing that the art of reading in the lines of the hand is part of physiognomy. ${ }^{85}$ Moreover, he bases palmistry conceptually on a theory reminiscent of the Paracelsus concept of signatures that allows one to deduce the value of things from their external appearance. ${ }^{86}$ This interesting small publication, which was possibly only the beginning of a larger project, ${ }^{87}$ was not printed until the $20^{\text {th }}$ century and went rather unnoticed despite Marzio da Narni's considerable reputation as a physiognomist. ${ }^{88}$

Giovanni Battista Della Porta, the most emblematic author of physiognomic studies, also devoted himself to metoposcopy and chiromancy, but both studies were published only posthumously, in 1677, both in a loose edition and as an appendix to Magia naturalis. Poma (2010, 118-119) dates the drafting of the chiromantic treatise between 1603 and 1608. Thanks to the correspondence with Federico Cesi, we know that between 1608 and 1610, Della Porta had put a lot of effort, although without success, into seeing his short book published. ${ }^{89}$ However, the founder of the Accademia dei Lincei was careful to preserve the unpublished

82 Bujanda (1996, X, 387).

83 In fact, the lord of Rimini died in exile in Rome after being thrown out of his signoria in 1503 by Cesare Borgia according to Paolo Giovio in his Elogia (1972, 79-80).

84 See Briggs (1974, 75), Vasoli (1977), Galeotto Marzio e l'umanesimo italiano ed europeo (1983), Porter (2005, 13), Miggiano (2008), Federici Vescovini (2011, 97-98).

85 See Castelli (2006, 502-503).

86 See D'Alessandro $(1994,168)$.

87 See D’Alessandro $(1994,166)$.

88 See Frezza (1951, LIII-LIV) in his edition of Marzio da Narni’s Chiromanzia.

89 See for details the introduction to the edition of Trabucco (2003, XI-XIII) and Verardi (2011b, 51). 
manuscripts of his friend with the intention of publishing them as soon as possible. Another linceo, Francesco Stelluti, promised in the prologue of his synoptic edition of Della fisionomia di tutto il corpo umano di Signor Giovanni Battista Della Porta ora brevemente in tavole sinottiche ridotta (Roma, Vitale Mascardi, 1637) a reprint of this book, with more illustrations, which would be accompanied by "un curioso trattato della mano dell'uomo paragonata alli piedi d'alcuni animali quadrupedi, e di uccelli" (1637, without pagination) [a curious treatise of the hand of man compared to the feet of some quadruped animals, and birds]. It was finally Pompeo Sarnelli, the publisher of Magia naturale in Italian, who - within the framework of "un nuovo programma di recupero dell'opera del filosofo napoletano" (Trabucco in his introduction to Della Porta 2003, XIX) [a new program to salvage the work of the Neapolitan philosopher] - published the treatise on palmistry. Sarnelli also wrote a Proemio in which he insisted on the scientific status of palmistry and its legality, relying on the authority of Martin del Rio. ${ }^{90}$ Della Porta himself complained in his prologue about the circulation of "scritti d'ignoranti ciurmatori, come di Tricassio et Andrea Corvo, che erano impostori e saltimbanca" 91 [The writings of ignorant charlatans, as of Tricassio and Andrea Corvo, who were impostors and tricksters]. In his own work, the Neapolitan scholar tries to guarantee the validity of palm reading by subordinating it to the theoretical principles of physiognomy. ${ }^{92}$ Della Porta himself describes his empirical methodology in his Proemio with all the gruesome details:

Et acciò che havessi abbondanza degli huomini sopra accennati, convenni col boia napolitano, ch'era all'hora un certo, nominato Antonello Cocozza, che quando egli deponeva dalle forche gli appiccati, e gli portava al Ponte Ricciardo [. . .] mi avisasse l'hora di quella trasportatione. Et io, andando a quel luogo, osservava le dispositioni delle mani e de' piedi, e quelle disegnava con uno stilo nelle carte a ciò destinate, oppure con il gesso ne formava i lor cavi, acciò che buttandovi doppo la cera ne havessi in casa i lineamenti, e da ciò havessi campo di studiarvi la notte in casa e di conferirli con gl'altri; e conferiti

90 See the "Proemio di Pompeo Sarnelli", in Della Porta, ed. Trabucco (2003, 83): "Ella è la chiromantia una scienza, la quale, per mezzo delle linee della mano, dà chiarissimo inditio del temperamento e complessione di ciascheduno, e da questo si viene ad indagare con qualche probabilità la lunghezza o brevità della vita, e le inchinationi dell'anima." [Chiromancy is a science, which, by means of the lines of the hand, gives a very clear indication of the temperament and complexion of any one, and from this comes to induce with some probability the length or shortness of life, and the inclinations of the soul].

91 “Proemio dell'autore”, Della Porta, ed. Trabucco (2003, 90). See also Poma (2010, 119).

92 See Poma $(2010,118)$

See Trabucco (1995, 283-284) and Verardi (2011b, 55). 
insieme i segni ne cavassi la verità, facendo sempre l'istesso, fin a tanto, che trovassi tutti i segni, che dinotano tal'uno dover essere sospeso; e così sodisfacessi a me stesso. ${ }^{93}$

[And so that I might have an abundance of the men mentioned above, I agreed with the executioner of Naples, who was then a certain Antonello Cocozza, who, when he took the bodies down from the gallows, and brought them to Ponte Ricciardo [. . .] gave me the time of that transport. And I, going to that place, observed the dispositions of their hands and feet, and drew them with a stylus on the papers intended for that purpose, or I formed with plaster their shape, so that by throwing them in the wax afterwards I could have their features at home, and from that I could study them at night and compare them with others; and, putting all the signs together, I could find out the truth, and doing the same till I could find all the signs, that show that someone is to be hanged; and so I satisfied myself.]

This description recalls the activities of the women of Celestina's lineage and shows that certain scientific practices were still relegated to a marginalised world, as was the case in Fernando de Rojas' time with anatomical studies.

The Italian philosopher and poet Tommaso Campanella (1568-1639) wrote, during his Parisian exile, a chiromantic treatise at the behest of none other than Cardinal Richelieu. As Ernst remarked, in France, "Campanella was appreciated in court circles for his astrological knowledge and understanding of the occult" (2010, 261), ${ }^{94}$ although his Chiroscopia is an unoriginal work, inspired in part by the Anastasis chiromantica of Cocles. ${ }^{95}$ Later, in the chapter "De signis" of his Dialectica, one of the five parts of the Philosophia rationalis, written between 1613-1619 and published in 1638, Campanella develops a semiotic theory that distinguishes between natural and artificial signs. According to Delumeau “il était persuadé que certains signes 'naturels' dans les astres, sur terres ou dans l'homme permettent en quelque façon de présager l'avenir" (2008, 259-260) [he was convinced that certain "natural" signs in the stars, on the earth or in man are in some way a harbinger of the future]. Likewise, in his Metaphysica (1623) the author of La città del sole (1602) dedicates articles II-VI of chapter XI of book XVI to the divinatory arts and defends the legality and veracity of palmistry and physiognomy, citing Aristotle and Della Porta. ${ }^{96}$

93 "Proemio dell'autore", Della Porta, ed. Trabucco (2003, 91-92). See about this anecdote Ernst (1995, 89) and Muratori (2017, 2).

94 Campanella went into exile in France in 1634 after several problems with the Roman Inquisition. See for his stay in the French capital Ernst (1995) and (2010, 243-266).

95 See Ernst (1995, 89).

96 Campanella, Dalla metaphysica, ed. Ernst (2007, 37); see also the editor's introduction (XV-XVIII). Also in the Del senso delle cose e della magica Campanella cites the PseudoAristotelian physiognomic manual, ed. Bruers (1925, 158). 
In France, two short chiromantic books were published in the 1660s: La science curieuse ou traité de la chyromance (Paris, François Clousier, 1665, 1667 and 1675), an anonymous text that is partly a translation of the Latin work of Jean Taisnier, and partly of an obscure character called Adrien Sicler, who styles himself "médecin spagyrique" [spagyric doctor].

Throughout the $15^{\text {th }}, 16^{\text {th }}$ and $17^{\text {th }}$ centuries, palmistry was a scientific practice to which renowned scholars devoted themselves. We do not only know of humanists who wrote about palm reading, but we even know that they put it into practice. The German humanist Joachim Camerarius (1500-1574) relates an episode about a palm reader who had seen in the hand of a young, healthy girl that she would die within eight days. The prognosis would have been verified after one week as he had been told by no lesser man than another humanist, Willibald Pirckheimer (1470-1530). ${ }^{97}$

\subsection{Palmistry marginalised: the gipsies}

Although palmistry is considered a scientific practice, worthy of the dedication of scholars, it is usually associated with the marginalised world of the gipsies since this people arrived in Europe at the beginning of the $15^{\text {th }}$ century, supposedly from Egypt. ${ }^{98}$ The Journal d'un bourgeois de Paris provides detailed information on the arrival of the gipsies in France in 1427:

Brief, ce estoient les plus povres creatures que on vit oncques venir en France de aage de homme. Et neantmoins leur povreté, en la compaignie avoit sorcieres qui regardoient es mains des gens et disoient ce que advenu leur estoit ou à advenir, et mirent contans en plusieurs mariaiges, car elles disoient (au mari): Ta femme (ta femme t'a fait) coux, ou à la femme: ton mari t'a fait coulpe. Et qui pis estoit, en parlant aux creatures, par art magique, ou autrement, ou par l'ennemy d'enfer, ou par entregent d'abilité faisoient vuyder les bourses aux gens, et le mettoient en leur bourse, comme on disoit. ${ }^{99}$

In short, they were the poorest creatures that have been seen coming to France since time immemorial. And despite their poverty, there were witches in the group who read in the hands of the people and told them what had happened in the past and what would happen in the future. And they stirred up strife among several married couples: for they said (to the husband), Thy wife hath made thee a cuckold, and to the wife, Thy husband hath

97 See Gernert (2013c, 46).

98 See for the history of the gipsies and their arrival in Europe Leblon (1985), Gómez Vozmediano (2005), Aguirre Felipe (2008) and Rheinheimer (2009, 159-167) and for the magical practices of the gipsies Leland (1962).

99 Tuetey $(1881,220)$. 
deceived thee. And what was worse, talking to those creatures, by magic art, or otherwise, or with help of the enemy of hell, or by skill, they made people have their purses emptied, and put it in their purses, as they say.

The anonymous chronicler also reports on the reaction of the church authorities to these divinatory practices carried out by the bohemians and the sanctions against their clients. ${ }^{100}$ The German physician Johann Hartlieb (ca. 1400-1468) associates in chapter 103 ("Von den zygeinern, wie sy die ainvaltigen laichen" [About the gipsies aand how they betray the simpletons]) of his anti-superstitious treatise Das puch aller verpoten kunst ("The book of all forbidden arts") chiromancy with the gipsies. ${ }^{101}$ Throughout the $16^{\text {th }}$ and $17^{\text {th }}$ centuries there is a lot of documentation about the gipsies ${ }^{102}$ and especially the palmreading gipsy women. ${ }^{103}$ Tomaso Garzoni observes in his Piazza universale (1585):

E oggidì è tanto avilita quest'arte ch'i cingari soli [. . . ] attendono a quella, dando, con spasso e trastullo del mondo, buona ventura a tutti, guardando su la mano, e dicendo mille novelle alle paparote massimamente, non con minor falsità che gioco, essendo da tutti stimata una professione ridicola ed erronea da dovero. ${ }^{104}$

[And today this art is so humbled that only the gipsies are practising it, awarding, to the joy and amusement of the world, good fortune to all, looking up one's hand, and saying a thousand novelties to the utmost stupid, with no less falsehood than play, being esteemed by all as a ridiculous and erroneous profession in truth.]

Anti-superstitious writers such as Martín del Río or Juan de Horozco y Covarrubias condemn chiromancy as a deceitful art, invented by the gipsies. In Spain, during the first half of the $17^{\text {th }}$ century, treaties against the gipsies were

100 "Et vrayement, je and fu III ou IIII foys pour parler à eulx, mais oncques ne m'aperceu d'ung denier de perte, ne les vy regarder en main, mais ainsi le disoit le peuple partout, tant que la nouvelle en vint à l'evesque de Paris, lequel and alla et mena avecques lui ung frere meneur, nommé le Petit Jacobin, lequel par le commandement de l'evesque fist là une belle predicacion en excommuniant tous ceulx et celles qui se faisoient et qui avoient creu et monstré leurs mains", Tuetey (1881, 220-221) [And truly, I went there three or four times to speak to them, but I did not lose a penny, nor did I see them looking at people's hands, but thus said the people everywhere. When the news came to the bishop of Paris, he went there and took with him a Friar Minor, called Petit Jacobin, who by the bishop's command made a beautiful sermon there, excommunicating all those who have shown their hands and believed what they were told].

101 Hartlieb, Das Buch der verbotenen Künste, ed. Eisermann \& Graf (1998, 170).

102 See in this regard Caro Baroja (1993, 17), Solms (2008, 51-62) and Tuczay (2012, 80-82).

103 See Predari (1841, 102), Gutiérrez Nieto (1993, 997), Aguirre Felipe (2009, 86-87), and Castelli (2006, 506-510).

104 Garzoni, La piazza universale di tutte le professioni del mondo, ed. Cherchi and Collina $(1996,676)$. 
published, such as the discourse entitled Expulsión de los gitanos (1619) by Sancho de Moncada or the Discurso contra los gitanos (1631) by Juan de Quiñones, which reiterated the censure of predicting good fortune.

Chiromancy as a divinatory art practised by gipsies is a well-established literary motif. One of the most famous readers of the lines of the hand in Spanish literature is perhaps the protagonist of Cervantes' exemplary novel La Gitanilla. 